\title{
Thermal and Acoustic Insulating Gypsum Composite Material with Improved Water Resistance
}

\author{
Volodimir Kersh, Andriy Kolesnikov, Mikola Hlitsov, Sergii Gedulyan
}

\begin{abstract}
The article discusses methods for obtaining building heat and sound insulating composite material based on gypsum with high resistance to water. An additional characteristic is considered - the water resistance index, in which the role of material strength in the wet state is enhanced. The proposed characteristic is used to optimize the heat and sound insulating composition based on gypsum. The material contains matrix gypsum-cement-ash binder and a mixture of aggregates. The result of the planned experiment shows that the water resistance index more adequately reflects the strength of the composite in the wet state compared to the softening coefficient. An optimization of the complex properties of the composite is given in accordance with its intended purpose. As a result of the study, an optimal waterproof composition with improved thermal insulation and sound insulation characteristics was obtained.
\end{abstract}

Keywords: experimental statistical modeling; gypsum-containing composite; hierarchical optimization; softening coefficient; water resistance index

\section{INTRODUCTION}

One of the main tasks of modern building materials science is the development and implementation of materials characterized by improved operational, technological, and environmental qualities. Specific requirements, a high curing rate in particular, are imposed on materials for the manufacture of bases for self-leveling floors, as well as molding partitions $[1,2]$. Gypsum and gypsum-containing composites are promising for improving thermal and acoustic comfort [3, 4]. In some cases, their use is limited to a significant decrease in strength when wetting products from those composites, especially with loose aggregates (for example, perlite, sawdust, etc.) [5], up to unprompted destruction in a water-saturated state.

The increase in water resistance of gypsum composites is carried out mainly in two directions:

1. Creating effective mixtures based on gypsum and cement with the mandatory addition of components with pozzolanic activity (ash and slag, tripoli, flask) $[6,7]$.

2. Internal and surface hydrophobization $[8,9]$.

The use of these techniques simultaneously leads to a synergistic enhancement of the water resistance of materials based on gypsum.

It is possible to increase the heat and sound insulation characteristics of the materials under consideration by adding to the mixture non-traditional aggregates with low density, low thermal conductivity and sound permeability - expanded polystyrene, cork crumb and granulated foam glass.

\section{MATERIALS AND METHODS}

Of the many multi-piece compositions that are applicable in considered areas, materials with an optimal set of performance properties are currently in demand, with the most significant performance properties being characterized by values close to optimal, and the rest - satisfying a set of regulatory requirements and restrictions [10]. For the intended use of the gypsum composite (base for floors), along with optimal thermal conductivity (minimum), sound permeability for airborne and impact noise (minimum), compressive strength (maximum), an important characteristic is water resistance (maximum). Presence of multi-criteria optimization problem for the composites along with restrictions that comply with the regulations standards is under consideration. Let us consider in more detail the characteristics of water resistance.

Water resistance of materials is usually estimated by a softening coefficient, equal to the ratio of compressive strengths in water-saturated and dry condition [6]: $K_{\mathrm{s}}=$ $R_{\mathrm{W}} / R_{\text {dry }}$. The coefficient of softening of products from pure gypsum $K_{\mathrm{p}}=0.3-0.5$, which indicates its low water resistance.

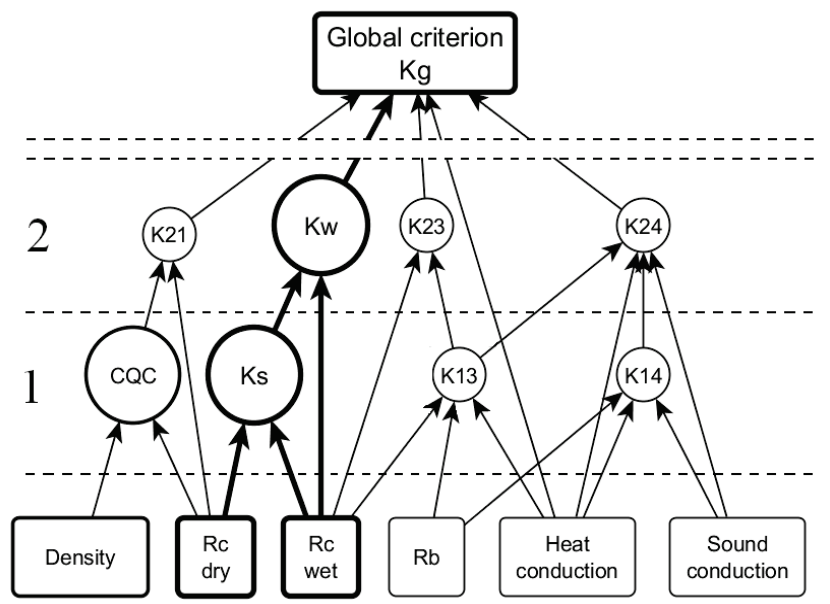

Figure 1 The hierarchical nature of the composite material's optimality criteria; $K_{\mathrm{s}}$ softening coefficient, $K_{\mathrm{w}}$ - proposed water resistance index, $C Q C$-coefficient of structural quality, $R_{\mathrm{c}}(\mathrm{dry})$ - compressive strength in the dry state, $R_{\mathrm{c}}($ wet $)-$ compressive strength in a water-saturated state

Along with the widespread softening coefficient, another characteristic seems to be useful - water resistance index $K_{\mathrm{w}}$, coefficient in which the value of wet strength is 
"strengthened" as determining the possibility of using the material for wetting, $K_{\mathrm{w}}=R_{\mathrm{wet}}^{2} / R_{\text {dry }}$ [11]. As will be shown later, $K_{\mathrm{w}}$ more accurately characterizes the water resistance of a material.

It is convenient to consider these characteristics of water resistance as certain particular combined criteria located on different tiers in a multi-criteria optimization scheme between individual performance characteristics and the hypothetical global $\mathrm{Kg}$ criterion (Fig. 1).

Another example of partial criteria of an intermediate nature is the known coefficient of structural quality of a material [12] (CQC, Fig. 1), equal to the ratio of compressive strength of a composite to its density, $C Q C=R_{\mathrm{c}} / d$, which is useful for assessing the effectiveness of structural materials. This criterion, as a softening coefficient and water resistance index, is an element of a general hierarchical scheme for optimization of composites.

The features of water resistance characteristics are appeared during the optimization of a composite material based on a gypsum-cement-ash binder with the addition of heat and sound insulating aggregates (Tab. 1).

Table 1 The composition of the samples of the cement composition in the planned experiment

\begin{tabular}{|c|c|c|c|c|}
\hline \multirow{2}{*}{ № } & \multicolumn{5}{|c|}{ Coded values } \\
\cline { 2 - 5 } & Poly-styrene & Cork & Foam glass & Ash \\
\hline 1 & 0 & 1 & 0 & 1 \\
\hline 2 & 0.5 & 0 & 0.5 & 1 \\
\hline 3 & 0.33 & 0.33 & 0.33 & -1 \\
\hline 4 & 0 & 0 & 1 & -1 \\
\hline 5 & 0.5 & 0.5 & 0 & 1 \\
\hline 6 & 0 & 0.5 & 0.5 & -1 \\
\hline 7 & 1 & 0 & 0 & 1 \\
\hline 8 & 1 & 0 & 0 & -1 \\
\hline 9 & 0.33 & 0.33 & 0.33 & 1 \\
\hline 10 & 0 & 1 & 0 & -1 \\
\hline 11 & 0.5 & 0 & 0.5 & -1 \\
\hline 12 & 0 & 0 & 1 & 1 \\
\hline 13 & 0 & 0.5 & 0.5 & 1 \\
\hline 14 & 0.5 & 0.5 & 0 & -1 \\
\hline
\end{tabular}

\section{RESULTS AND DISCUSSION}

The main operational characteristics of the samples are investigated, including compressive strength in dry $R_{\text {dry }}$ (MPa) and water-saturated $R_{\text {wet }}(\mathrm{MPa})$ condition. For a qualitative comparison of the water resistance characteristics of $\mathrm{Ks}$ and $\mathrm{Kw}$, according to the degree of approximation $R_{\text {wet, }}$, all values are normalized to unity by the formula $X_{\text {norm }}=\left(X-X_{\min }\right) /\left(X_{\max }-X_{\min }\right)$, where $X-$ the initial property value for each sample, $X_{\max (\min )}$ - the maximum (minimum) value by sampling. The corresponding normalized values are shown in Fig. 2.

When comparing the normalized values of the characteristics of water resistance displayed in Fig. 2, it can be seen that for samples № 3, 8 and 14 (Fig. 2a) the softening coefficient $K_{\mathrm{s}}$ represents a clearly overestimated estimate of water resistance in terms of its main "target" parameter -

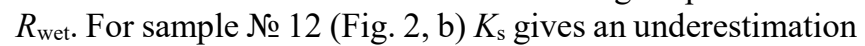

of water resistance. The water resistance index $K_{\mathrm{w}}$ in all these cases reflects the water resistance more adequately.

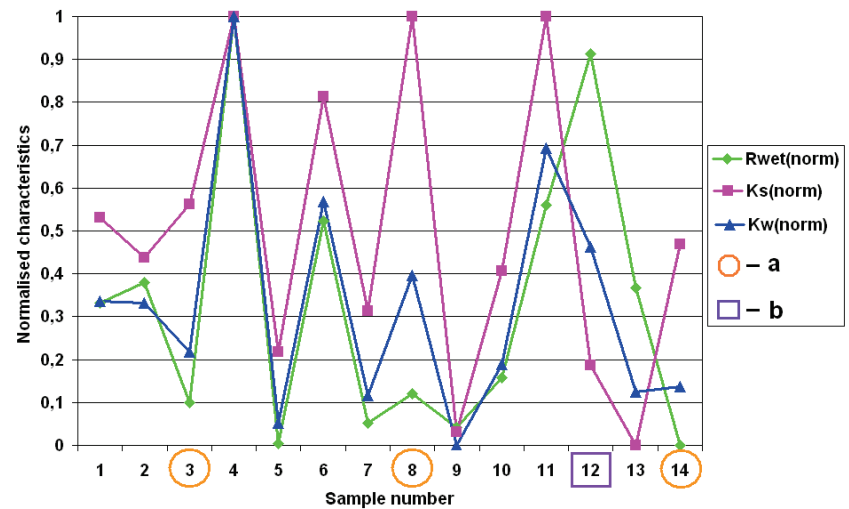

Figure 2 Normalized water resistance characteristics of the composite a - an overestimation of water resistance by $K_{\mathrm{s}}, \mathrm{b}-$ is an underestimation of water resistance by $K_{\mathrm{s}}$. Water resistance index $K_{\mathrm{w}}$ adequately assesses water resistance.
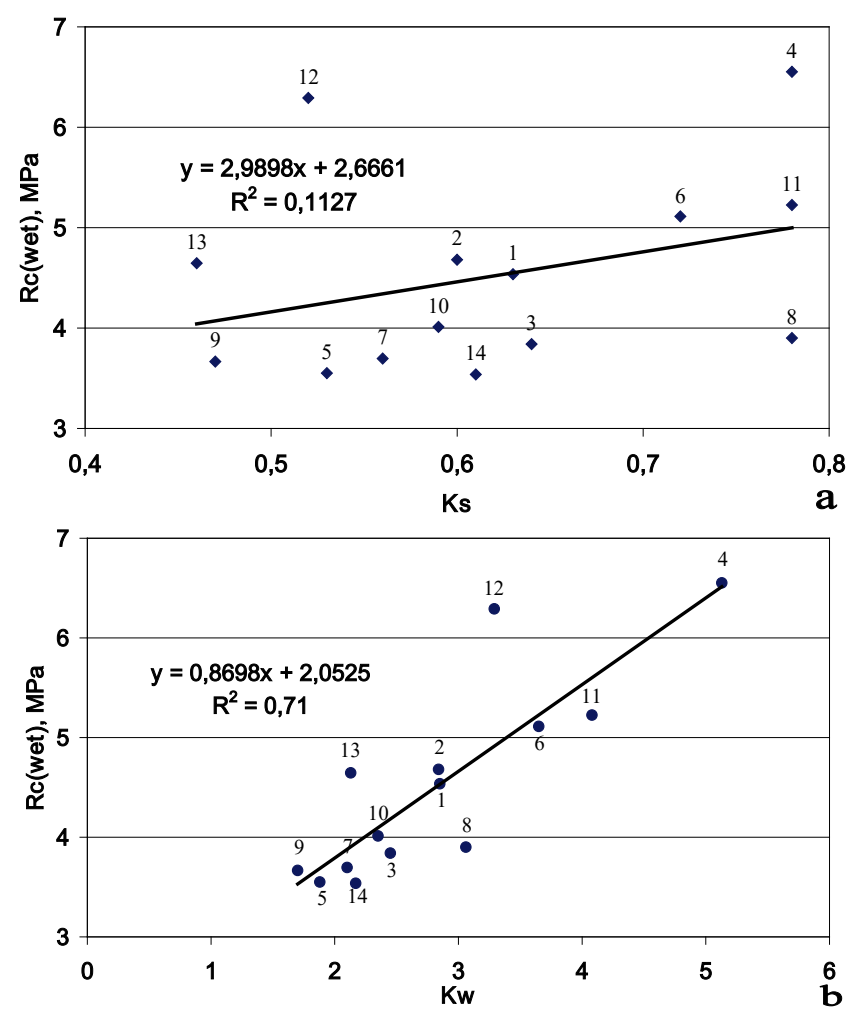

Figure 3 The nature of bond of strength in a water-saturated state of the softening coefficient $K_{\mathrm{s}}$ (a) and the water resistance index $K_{\mathrm{w}}$ (b)

The study of the statistical characteristics of the water resistance of 14 samples confirms this conclusion. The nature of bond of strength in a water-saturated state with a softening coefficient and water resistance index is shown in Fig. 3. No significant correlation of the softening coefficient $K_{\mathrm{s}}$ with the strength in the wet state $R_{\text {wet }}$, MPa is observed (Fig. 3a). At the same time, there is a clear correlation between the strength in a water-saturated state and the water resistance index, with the coefficient of determination $R^{2}=0.71$ (Fig. 3b). 
An additional advantage of the water resistance index in the task is its high discriminatory ability in a comparative analysis - it allows you to better distinguish the compositions by water resistance (Fig. 4).

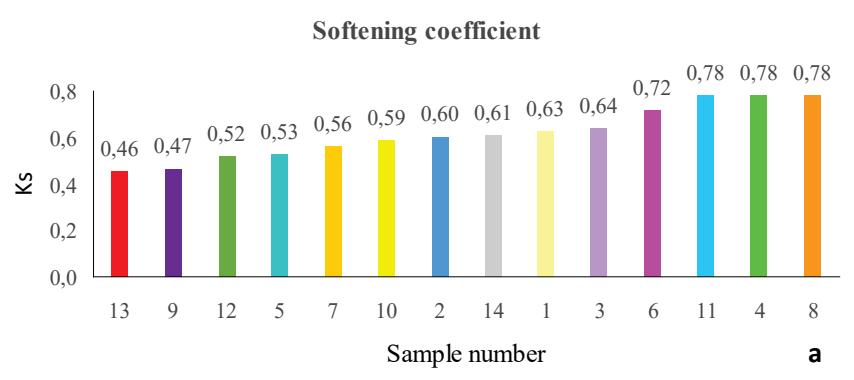

Water resistance index

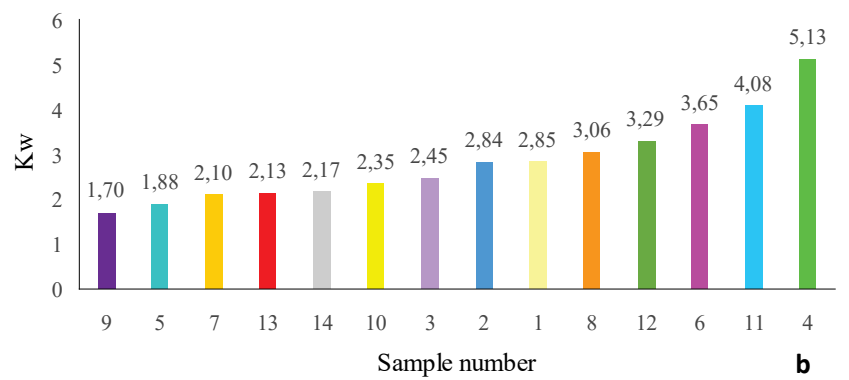

Figure 4 The softening coefficient $K_{\mathrm{s}}(\mathrm{a})$ and the water resistance index $K_{\mathrm{w}}(\mathrm{b})$ in a comparative analysis of multi-piece compositions.

Table 2 Experimental statistical models of water resistance

\begin{tabular}{|c|c|c|c|}
\hline \multicolumn{2}{|c|}{ Softening coefficient $K_{\mathrm{s}}=$} & \multicolumn{2}{|c|}{ Water resistance index $K_{\mathrm{w}}=$} \\
\hline \multicolumn{2}{|c|}{$+0.6808 *$ Polystyrene } & \multicolumn{2}{|c|}{$+2.5723 *$ Polystyrene } \\
\hline \multicolumn{2}{|c|}{$+0.6119 *$ Cork } & \multicolumn{2}{|c|}{$+2.6450 *$ Cork } \\
\hline \multicolumn{2}{|c|}{$+0.6590 *$ Foam glass } & \multicolumn{2}{|c|}{$+4.2009 *$ Foam glass } \\
\hline \multicolumn{2}{|c|}{$-0.3593 *$ Polystyrene $*$ Cork } & \multicolumn{2}{|c|}{$-3.0707 *$ Polystyrene $*$ Cork } \\
\hline \multicolumn{2}{|c|}{$-0.0964 *$ Polystyrene $*$ Ash } & \multicolumn{2}{|c|}{$-0.3885 *$ Polystyrene $*$ Ash } \\
\hline \multicolumn{2}{|c|}{$-0.2443 *$ Cork $*$ Foam glass } & \multicolumn{2}{|c|}{$-2.8576 *$ Cork $*$ Foam glass } \\
\hline \multicolumn{2}{|c|}{$+0.0201 *$ Cork $*$ Ash } & \multicolumn{2}{|c|}{$-0.9898 *$ Foam glass*Ash } \\
\hline \multicolumn{4}{|c|}{$-0.1189 *$ Foam glass $*$ Ash } \\
\hline \multicolumn{4}{|c|}{$-0.2976 *$ Cork $*$ Foam glass $*$ Ash } \\
\hline R-Squared & 0.9656 & R-Squared & 0.9328 \\
\hline Adj R-Squared & 0.9106 & Adj R-Squared & 0.8752 \\
\hline Pred R-Squared & 0.6781 & Pred R-Squared & 0.7776 \\
\hline Adeq Precision & 12.323 & Adeq Precision & 14.890 \\
\hline
\end{tabular}

An analysis of the water resistance of a composite based on the softening coefficient (Fig. 4, a) equalizes by water resistance samples № 11, 4, $8\left(K_{\mathrm{s}}=0.78\right)$. At the same time, the most significant performance characteristic related to water resistance $-\mathrm{R}_{\text {wet }}-$ is different for this samples: № 4 has $R_{\text {wet }}=6.6 \mathrm{MPa}$, № 8 has $R_{\text {wet }}=3.9 \mathrm{MPa}$, y № $11 R_{\text {wet }}=5.2$ $\mathrm{MPa}$. The softening coefficient $\mathrm{K}_{\mathrm{s}}$ does not reflect this difference. At the same time, the water resistance index $K_{\mathrm{w}}$ more adequately reflects water resistance (Fig. 4, b).

We will conduct a comparative analysis of the effectiveness of using the water resistance index and the softening coefficient as responses in the planned experiment to optimize the composite. Experimental statistical models of these characteristics of resistance are shown in Tab. 2.

Graphic display of the resulted models is shown in Fig. 5 and 6 . The softening coefficient (Fig. 5) takes the highest value with the minimum ash concentration $($ Ash $=-1)$. In terms of the composition of the aggregate mixtures, the maximum $K_{\mathrm{s}}$ corresponds to a composite without cork components - the cork granules absorb water and swell, which contributes to the destruction of wet material. At the same time, the effect of polystyrene and foam glass, which do not absorb water, is almost the same - a line of compositions is observed with the same level of softening coefficient $\left(K_{\mathrm{s}}=0.8\right)$.
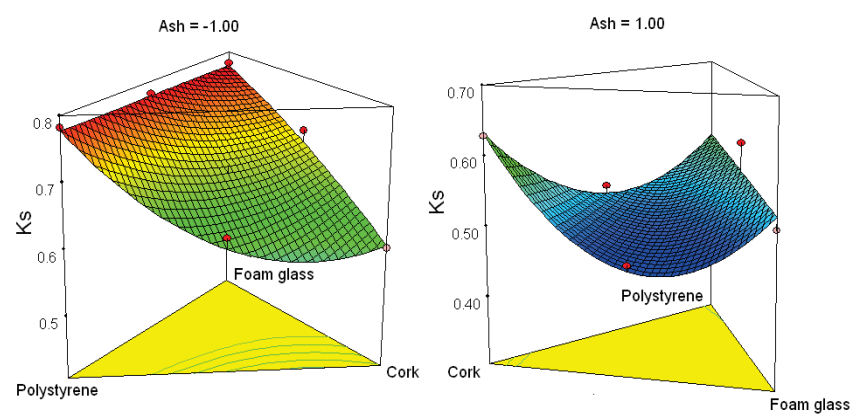

Figure 5 Display of experimental statistical models of the softening coefficient $K_{\mathrm{s}}$

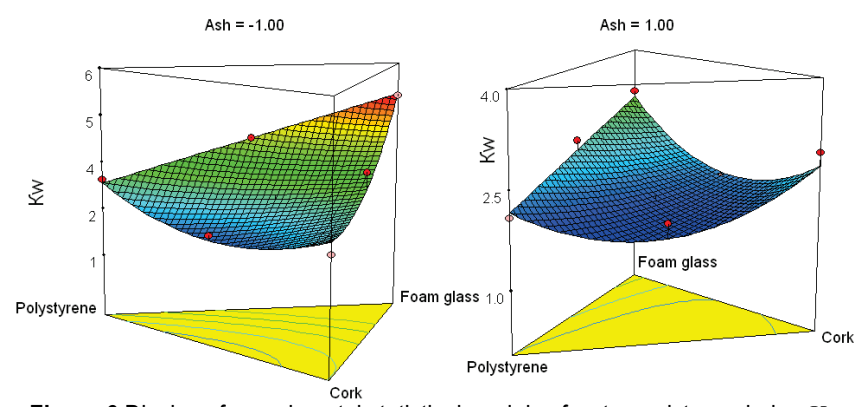

Figure 6 Display of experimental statistical models of water resistance index $K_{\mathrm{w}}$

The highest value of the water resistance index (Fig. 6) is characteristic of the composition with the minimum ash content $($ Ash $=-1)$ and the maximum foam glass content. A possible explanation for the positive effect of foam glass on the water resistance of the composite is the insularity of cells, as well as the increased strength of the adhesive contacts of the matrix material and foam glass. Cork filler reduces material strength under load due to swelling.

The peculiarity of the problem of optimization of water resistance of materials with the help of the proposed characteristic is the ability to maximize the water resistance index, while maintaining only the boundary requirements for the softening coefficient that are consistent with accepted standards. The considered characteristics together with other properties (heat engineering, acoustic, etc.) can be used in solving multi-criteria optimization problems.

With geometric optimization, areas corresponding to suitable compositions are distinguished on the factor plane. To implement this method, in accordance with the requirements for the materials of the type under consideration, the allowable limits for changes in performance properties are set (Tab. 3).

The diagram of geometric optimization, performed on the models of operational properties, is shown in Fig. 7. For the minimum ash content $($ Ash $=-1)$, the range of permissible 
compositions is near the center of the triangle; all components of the aggregate mixture must be present. This can be interpreted as follows. Aggregates that are together in use in the composite, at their optimal proportions, mutually reinforce the positive properties of each other and partially neutralize the negative ones. At maximum ash concentrations $($ Ash $=1)$, no allowable areas are found.

Table 3 Allowable variation ranges for composite properties

\begin{tabular}{|l|c|c|c|}
\hline \multicolumn{1}{|c|}{ Characteristics } & Denotement & Units & Values \\
\hline Density & $d$ & $\mathrm{~kg} / \mathrm{m}^{3}$ & $900-1100$ \\
\hline Compressive strength & $R_{\mathrm{c}}$ & $\mathrm{MPa}$ & $5-10$ \\
\hline Flexural strength & $R_{\mathrm{b}}$ & $\mathrm{MPa}$ & $0.5-1$ \\
\hline Thermal conductivity & $\lambda$ & $\mathrm{W} /(\mathrm{m} \cdot$ degree $)$ & $0,2-0,25$ \\
\hline $\begin{array}{l}\text { Sound permeability } \\
\text { coefficient }\end{array}$ & Air noise & - & $0.003-0.05$ \\
\hline $\begin{array}{l}\text { Impact noise (average } \\
\text { amplitude) }\end{array}$ & Blow noise & $\mathrm{MB}$ & $700-1000$ \\
\hline Softening coefficient & $K_{\mathrm{s}}$ & - & $0.6-1$ \\
\hline Water resistance index & $K_{\mathrm{w}}$ & $\mathrm{MPa}$ & $3-5$ \\
\hline
\end{tabular}

Table 4 Optimization criteria and objectives

\begin{tabular}{|c|c|c|c|c|}
\hline \multicolumn{2}{|c}{ Table 4 Optimization criteria and objectives } \\
\hline Criteria & $\begin{array}{c}\text { Optimization } \\
\text { objectives }\end{array}$ & Lower limit & Upper limit & $\begin{array}{c}\text { Degree of } \\
\text { importance }\end{array}$ \\
\hline$d$ & minimize & 900 & 1100 & 2 \\
\hline$R_{\mathrm{c}}$ & maximize & 5 & 12.1 & 4 \\
\hline$R_{\mathrm{b}}$ & in the range & 0.5 & 1.06 & - \\
\hline$\lambda$ & minimize & 0.2 & 0.25 & 4 \\
\hline Air noise & minimize & 0.025 & 0.05 & 3 \\
\hline Blow noise & minimize & 700 & 1000 & 4 \\
\hline$K_{\mathrm{s}}$ & in the range & 0.6 & 1 & - \\
\hline$K_{\mathrm{w}}$ & $\begin{array}{c}\text { maximize } \\
\text { maximize }\end{array}$ & 3 & 5 & 4 \\
\hline
\end{tabular}

Another option is numerical optimization, in which the considered properties, which play the role of partial optimality criteria, are minimized to a single criterion, the "desirability function" [13-15] (Desirability). The objectives and optimization criteria, as well as the degree of importance of each of the exploited performance properties are shown in Tab. 4.

As a result of optimization, the most successful prescription solutions were selected (Tab. 5).

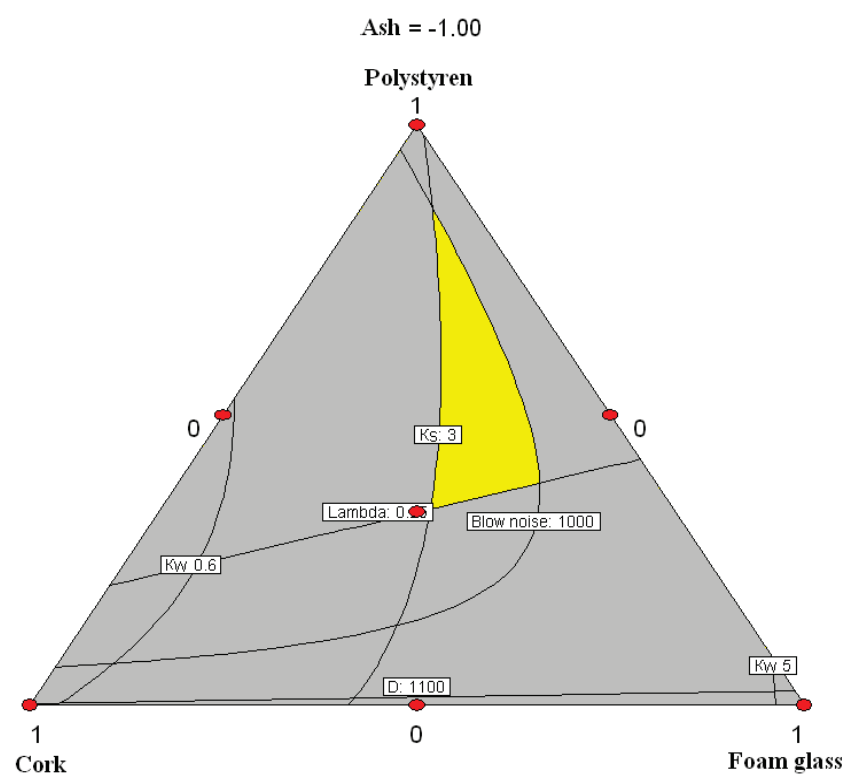

Figure 7 The range of allowable compositions of the studied composite

Table 5 Numerical optimization results

\begin{tabular}{|c|c|c|c|c|c|c|c|c|c|c|c|c|c|}
\hline № & Polystyrene & Cork & Foam glass & Ash & $d$ & $R_{\mathrm{c}}$ & $R_{\mathrm{b}}$ & Lambda & Air noise & Blow noise & $K_{\mathrm{s}}$ & $K_{\mathrm{w}}$ & Desirability \\
\hline 1 & 0.575 & 0.136 & 0.289 & -1 & 1008 & 6.37 & 0.65 & 0.241 & 0.0335 & 972 & 0.73 & 3.21 & 0.19088 \\
\hline 3 & 0.532 & 0.156 & 0.313 & -1 & 1015 & 6.46 & 0.66 & 0.243 & 0.0336 & 969 & 0.72 & 3.22 & 0.18871 \\
\hline 5 & 0.522 & 0.145 & 0.333 & -1 & 1017 & 6.50 & 0.66 & 0.243 & 0.0336 & 977 & 0.73 & 3.29 & 0.18599 \\
\hline
\end{tabular}

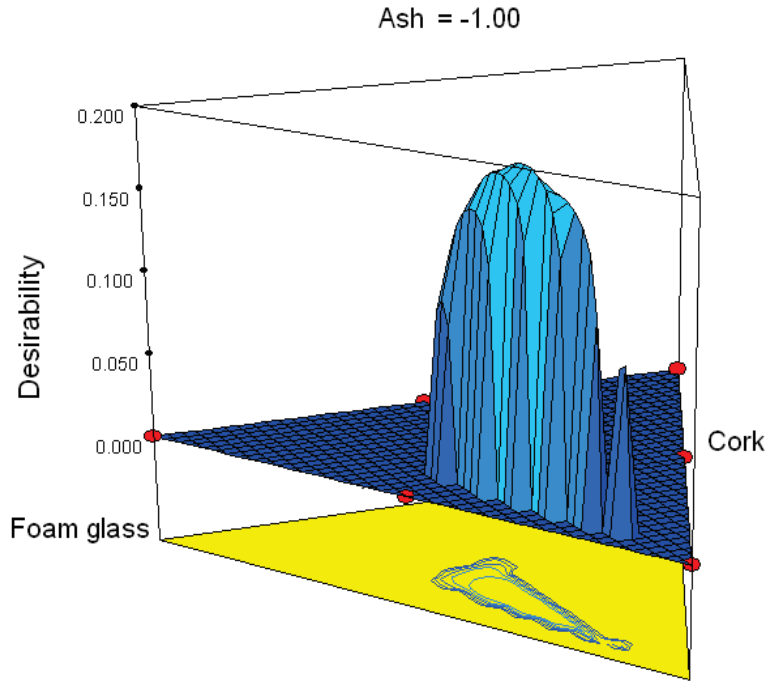

Polystyrene

Figure 8 Shape of the function of the desirability of the studied composite
For the function of desirability, sharp maxima are observed in the region of permissible compositions, each of them corresponds to the optimal composition (Fig. 8). Small values of this function indicate the materiality of the restrictions and the multidirectionality of the requirements for the optimal composition.

As a result of optimization, a composition with improved characteristics was obtained in comparison with matrix material without aggregates: thermal conductivity is reduced by about $50 \%$, sound insulation properties are improved by $35-50 \%$ for airborne noise and by $20-30 \%$ for impact noise. In this case, water resistance of the material is increased by 2 times $\left(K_{\mathrm{s}}=0,73, K_{\mathrm{w}}=3,21\right)$. The resulting composition meets the intended purpose.

The proposed water resistance index $K_{\mathrm{w}}$ makes it possible to more objectively and accurately assess the degree of water resistance of materials, and to compare them with each other by this feature, since it:

1. Is statistically determined - higher values of wet strength usually correspond to a higher water resistance index, 
which allows using it as an optimality criterion in materials science problems;

2. Has a clear physical meaning of given strength, $K_{\mathrm{w}}=$ $K_{\mathrm{s}} \cdot R_{\text {wet }}(\mathrm{MPa})$

3. Can be used as a particular or general optimality criterion for solving multi-criteria optimization problems for a complex of properties of composites.

\section{CONCLUSIONS}

1. A new water resistance characteristic of composite materials is being considered - the water resistance index, which has a number of advantages in comparison with the existing characteristics.

2. A hierarchical optimization scheme is proposed that combines the criteria for the quality of materials of varying complexity and generality, which allows purposefully forming a material with a set of specified characteristics.

3. The proposed approaches are applied to obtain the optimal formulation of the heat and sound insulating composite of high water resistance.

\section{REFERENCES}

[1] Korovyakov, V. F. (2003). Gipsovyie vyazhuschie i ih primenenie $\mathrm{v}$ stroitelstve. In Korovyakov, V. F. Himiya sovremennyih stroitelnyih materialov, 4, 18-25.

[2] Deshmukh, G., Birwal, P., Datir, R., \& Patel, S. (2017). Thermal Insulation Materials: A Tool for Energy Conservation. J Food Process Technol, 8, 670. https://doi.org/10.4172/2157-7110.1000670

[3] Ferronskoy, A. V. (2004). Gipsovyie materialyi i izdeliya (proizvodstvo i primeneniya). Spravochnik / Pod obsch. red. Ferronskoy, A. V. // M.: Izd-vo ASV, 488 p.

[4] Kersh, V. (2015). Structurally-Oriented Design of the Heat Insulation Plastering Material. In V. Kersh, A. Kolesnikov, T. Lyashenko, M. Pidkapka // No: Proceedings of REHVA Annual Conference 2015, Latvija, Rīga, 6.-9. maijs. Rīga: RTU PRESS, 241-244. https://doi.org/10.7250/rehvaconf.2015.033

[5] Kersh, V. Ya. (2013). Optimizatsiya strukturyi i svoystv teploizolyatsionnyih kompozitov na osnove ih diskretnyih modeley. Kersh, V. Ya., Kolesnikov, A. V., Fosch, A. V. // Visnik ODABA. - Odesa: Zovnish reklamservis, - Vip. 51, 256-260.

[6] Volzhenskiy, A. V. (1971). Gipsotsementno-putstsolanovyie vyazhuschie, betonyi i izdeliya. Volzhenskiy, A. V., Stambulko, V. I., Ferronskaya, A. V. // M.: Stroyizdat, 318 p.

[7] Kondraschenko, O. V. (2005). Gipsovi budivelni materiali pidvischenoyi mitsnosti i vodostiykosti (flziko-himichni ta energetichni osnovi): Avtoref. dis. d.t.n. / Kondraschenko, O. V. - Harkiv: UkrDAZT, 40 p.

[8] Suraev, V. B. (2002). Gidrofobizatsiya teoriya i praktika. Chast 1. InSuraev, V. B., Tehnologii stroitelstva, 1, 120-121.

[9] Li, J. (2007). The influences of gypsum waterproofing additive on gypsum crystal growth. Li, J., Li, G., \& Yu, Y. Materials Letters, 61, 872-876. https://doi.org/10.1016/j.matlet.2006.06.005

[10] Voznesenskiy, V. A. (1989). EVM i optimizatsiya kompozitsionnyih materialov. Voznesenskiy, V. A., Lyashenko, T. V., Ivanov, Ya. P., \& Nikolov, I. I. // K.: Budivelnyik, $312 \mathrm{p}$.
[11] Kersh, V. Ya. (2017). Opisanie vodostoykosti gipsosoderzhaschih kompozitsiy $\mathrm{s}$ pomoschyu kombinirovannogo kriteriya. Kersh, V. Ya., Kolesnikov, A. V., Fosch, A. V.: Zbirnik naukovih prats Ukrayinskogo derzhavnogo universitetu zaliznichnogo transportu, Harkiv, 168, 133-139.

[12] Dvorkin, L. I. (2011). Stroitelnyie mineralnyie vyazhuschie materialyi. Dvorkin, L. I., Dvorkin, O. L. // M.: InfraInzheneriya, $544 \mathrm{p}$.

[13] Adler, Yu. A. (1976). Planirovanie eksperimenta pri poiske optimalnyih usloviy. Adler, Yu. A., Markova, E. V., Granovskiy, Yu. V. // M.: Nauka, 376 p.

[14] Lotov, A. V. (2008). Mnogokriterialnyie zadachi prinyatiya resheniy. Lotov, A. V., Pospelova, I. I. // M.: Maks Press, 198 p.

[15] Kersh, V. Ya. (2016). Optimizatsiya uteplyayuschey shtukaturnoy kompozitsii metodami funktsii zhelatelnosti. In Kersh, V. Ya., Kolesnikov, A. V., \& Hlyitsov N. V., Modelirovanie $i$ optimizatsiya kompozitsionnyih stroitelnyih materialov: mezhdunarodnyiy nauchno-tehnicheskiy seminar: materialyi seminara, OGASA, Odessa, 52-56.

\section{Authors' contacts:}

Volodimir Yakovich Kersh, PhD, Professor

Odessa State Academy of Civil Engineering and Architecture

Didrihsona str. 4, Odessa 65029, Ukraine

E-mail: kersh@i.ua

Andriy Valeriyovich Kolesnikov, PhD, Assistant Professor

Odessa State Academy of Civil Engineering and Architecture

Didrihsona str. 4, Odessa 65029, Ukraine

E-mail: kolesn@stikonet.od.ua

Mikola Volodymyrovich Hlitsov, PhD, Associate Professor Odessa State Academy of Civil Engineering and Architecture Didrihsona str. 4, Odessa 65029, Ukraine

E-mail: color-t@mail.ru

Sergii Ivanovich Gedulyan, PhD, Associate Professor (Corresponding author)

Odessa State Academy of Civil Engineering and Architecture

Didrihsona str. 4, Odessa 65029, Ukraine

E-mail: sged@ukr.net 